\title{
THE DISTRIBUTION OF RADIOACTIVE MYOINOSITOL IN THE REPRODUCTIVE TRACT OF THE MALE RAT
}

\author{
LAWRENGE M. LEWIN AND SOREL SULIMOVICI \\ Department of Chemical Pathology, Tel Aviv University-Sackler Medical School, and \\ Institute of Endocrinology, Chaim Sheba Medical Center, Tel Hashomer, Israel
}

(Received 4th November 1974)

In various mammalian species, high concentrations of myoinositol have been found in seminal fluid and in male reproductive organs (Mann, 1964; Eisenberg $\&$ Bolden, 1964). In the work reported here, the fate of radioactive myoinositol after intraperitoneal injection was studied in mature male rats and in bilaterally nephrectomized rats, because they cannot catabolize myoinositol (Howard \& Anderson, 1967). The distribution of radioactivity among the male reproductive organs and glandular secretions was similar in bilaterally nephrectomized and intact animals (Table 1). Radioactive inositol was accumulated avidly, within $2 \mathrm{hr}$, by the coagulating gland and seminal vesicle, whereas the prostate, epididymis and ductus deferens concentrated inositol less actively. Approximately $24 \mathrm{hr}$ was required for the radioactivity (d/min/g wet wt) of the secretion of the coagulating gland, seminal vesicle or prostate to equal that of the gland itself. The inability of the testis to concentrate inositol was surprising, since the testicular concentration of inositol was quite high $(530 \mu \mathrm{g} / \mathrm{g}$ wet $\mathrm{wt})$ compared to that of blood $(11 \mu \mathrm{g} / \mathrm{ml})$. Likewise, the ram testis has been reported to synthesize myoinositol from glucose, in preference to utilizing preformed inositol present in the blood (Middleton \& Setchell, 1972). The mechanism might be analogous to testis-blood barriers for other substances (Dym \& Fawcett, 1970; Koskimies, Kormano \& Alfthen, 1973).

Eisenberg (1967) noted that the biosynthetic rate for myoinositol was much higher in the testis than in the accessory sex organs, and suggested that these organs might accumulate myoinositol by direct transport from the testis. To investigate this point, the specific activities of radioactive inositol in vesicular fluid, and in hydrolysates of testis, prostate, and coagulating gland were determined by a gas chromatographic method (Lewin, Szeinberg \& Lepkifker, 1973). Since the specific activity of inositol in the testis $(39 \mathrm{~d} / \mathrm{min} / \mu \mathrm{g}$ inositol) was much lower than that of the vesicular fluid $(413 \mathrm{~d} / \mathrm{min} / \mu \mathrm{g})$, coagulating gland $(233 \mathrm{~d} / \mathrm{min} / \mu \mathrm{g})$ or prostate $(319 \mathrm{~d} / \mathrm{min} / \mu \mathrm{g})$, it is unlikely that the labelled myoinositol passed through the testis before being concentrated by the accessory glands. This is consistent with the findings of Melampy \& Mason (1957), who showed that testosterone increased the myoinositol content of the accessory glands of castrated rats. On the basis of our data, it is likely that these glands concentrated myoinositol directly from the blood rather than by biosynthesis. 
It has been suggested by various workers that the essential rôle of myoinositol in cell physiology might be explained by the inositol phospholipids which are present in cellular and subcellular membranes (see Lewin, 1967 for review). The results of our investigations (Table 2) showed that most of the myoinositol in the testis, prostate, and seminal vesicles was found in the supernatant fluid after high-speed centrifugation, rather than in membrane-bound components of the cell, and labelled inositol was typically found to be soluble in $5 \%$ trichloracetic acid rather than in the lipid fraction. This was in contrast to the situation in the liver, where only $25 \%$ was found in the supernatant fluid and inositol lipid formed the major portion (approximately $60 \%$ ) of the accumulated labelled material.

Table 1. Distribution of radioactivity (d/min $/ \mathrm{g}$ wet wt $\times 10^{-3}$ ) in some organs and glandular secretions of intact and nephrectomized rats at various times after intraperitoneal injection of $\left[2 \cdot{ }^{3} \mathrm{H}\right]$ myoinositol

\begin{tabular}{lcccc}
\hline \multirow{2}{*}{ Organ or fluid } & \multicolumn{5}{c}{ Time after injection (hr) } \\
\cline { 2 - 6 } & 2 & 5 & 8 & 24 \\
\hline Whole blood & $27(27)$ & $36(36)$ & 49 & $26(41)$ \\
Testis & $16(33)$ & $20(34)$ & 43 & $33(51)$ \\
Epididymis & $198(81)$ & $161(74)$ & 86 & $(111)$ \\
Ductus deferens & $184(124)$ & $173(187)$ & 98 & $137(144)$ \\
Seminal vesicle & $741(437)$ & $778(427)$ & 293 & $501(340)$ \\
Seminal vesicle fluid & $50(88)$ & $235(111)$ & 127 & $570(343)$ \\
Coagulating gland & $517(208)$ & $993(642)$ & 423 & $767(519)$ \\
Coagulating gland fluid & $103(23)$ & $319(225)$ & 163 & $711(493)$ \\
Prostate & $274(305)$ & $388(212)$ & 161 & $441(222)$ \\
Prostatic fluid & $61(-)$ & $86(85)$ & 92 & $383(205)$ \\
& & & &
\end{tabular}

Male rats, 2 to 3 months old, weighing 275 to $350 \mathrm{~g}$, of the Charles River Strain, were injected intraperitoneally with $\left[2{ }^{3} \mathrm{H}\right]$ myoinositol $(8$ to $10 \mu \mathrm{Ci}$, sp. act. $4 \cdot 5 \mathrm{Ci} / \mathrm{mmol}$ ), dissolved in $0.5 \mathrm{ml}$ sterile saline $(0.85 \%)$. Animals were killed by a sharp blow on the head. Glandular fluids were expressed by gentle pressure applied with a syringe plunger. Tissue and fluid samples (approx. $100 \mathrm{mg}$ ) were digested overnight at room temperature, with $2 \mathrm{ml}$ Soluene 100 (Packard Instrument Co., Downes Grove, Illinois) and $13 \mathrm{ml}$ toluene-based scintillation fluid $(5 \mathrm{~g}$ of 2,5-diphenyloxazole and $50 \mathrm{mg}$ of 1,4-bis-2-(4methyl-5-phenyloxazolylbenzene/litre) were added. Radioactivity was measured using a Packard TriCarb Liquid Scintillation Spectrometer, with correction by the external standard method. Bilateral nephrectomy through a dorsal mid-line incision was performed under diethyl ether anaesthesia, leaving the adrenal glands in situ. The results for intact control rats are given in parentheses.

The high proportion of radioactivity found in the vesicular and prostatic supernatant fluids may reflect inositol in transit, which will later be secreted into the glandular fluid, or may indicate that this compound is important to the cell other than as a component of inositol lipids. 
Table 2. Distribution of radioactivity of $\left[2-{ }^{3} \mathrm{H}\right]$ myoinositol $\left(\mathrm{d} / \mathrm{min} / \mathrm{g}\right.$ wet $\left.\mathrm{wt} \times 10^{-3}\right)$ in subcellular fractions isolated from testis, prostate, liver and seminal vesicles of nephrectomized rats

\begin{tabular}{lrrrrr}
\hline $\begin{array}{c}\text { Subcellular } \\
\text { fraction }\end{array}$ & $\begin{array}{c}\text { Time after } \\
\text { killing }(\mathrm{hr})\end{array}$ & Testis & Prostate & $\begin{array}{c}\text { Seminal } \\
\text { vesicles }\end{array}$ & Liver \\
\hline & & & & & \\
$600 \mathrm{~g}$ & 5 & 7 & 7 & 12 & 31 \\
$600 \mathrm{~g}$ & 8 & 9 & 42 & 48 & 15 \\
$600 \mathrm{~g}$ & 24 & 11 & 19 & 20 & 24 \\
Mitochondrial & 5 & 4 & 11 & 6 & 31 \\
Mitochondrial & 8 & 2 & 3 & 7 & 15 \\
Mitochondrial & 24 & 5 & $\mathbf{4}$ & 3 & 28 \\
Microsomal & 5 & 1 & 8 & 4 & 4 \\
Microsomal & 8 & 1 & 7 & 3 & 3 \\
Microsomal & 24 & 3 & 5 & 5 & 13 \\
105,000 g supernatant & 5 & 32 & 278 & 375 & 11 \\
105,000 g supernatant & 8 & 42 & 218 & 462 & 7 \\
105,000 g supernatant & 24 & 47 & 187 & 251 & 32 \\
& & & & & \\
\hline
\end{tabular}

The radioactive tissue was weighed, pooled with similar tissue from non-radioactive rats, and homogenized in 5 vols ice-cold sucrose $(0.25 \mathrm{M})$. The homogenate was stored for $15 \mathrm{~min}$ to promote equilibration between labelled and unlabelled tissue, and was then centrifuged at $600 \mathrm{~g}$ for 15 min to sediment the nuclei and cell débris. The supernatant was decanted and retained, while the sediment was washed with 1 vol. sucrose $(0.25 \mathrm{M})$ and again centrifuged at the same speed for a further $15 \mathrm{~min}$. The combined supernatants were centrifuged at $10,000 \mathrm{~g}$ for $20 \mathrm{~min}$ to sediment the mitochondrial fraction, which was resuspended in $0.154 \mathrm{M}-\mathrm{KCl}$ by hand homogenization and centrifuged at $10,000 \mathrm{~g}$ for $10 \mathrm{~min}$. This procedure was repeated three times. The $10,000 \mathrm{~g}$ supernatant was further centrifuged at $105,000 \mathrm{~g}$ for $60 \mathrm{~min}$ to sediment the microsomal fraction, which was then resuspended in $0.154 \mathrm{M}-\mathrm{KCl}$ and centrifuged at $105,000 \mathrm{~g}$ for $60 \mathrm{~min}$. All of these operations were carried out at 0 to $4^{\circ} \mathrm{C}$. An aliquot $(0.1 \mathrm{ml})$ of each sample was mixed with $0.1 \mathrm{ml}$ of $18 \%(\mathrm{w} / \mathrm{v})$ Lubrol WX solution. The mixture was placed in a vial to which $10 \mathrm{ml}$ dioxane-based scintillation fluid had been added, and the radioactivity was determined as described.

This work was supported, in part, by the Ford Foundation Grant No. 67-470 to Professor Bruno Lunenfeld, and by a grant from the Ministry of Health, State of Israel, to Professor L. M. Lewin. We thank Mr S. Yosef, Mr Amos Gabso and Mrs Miriam Kaufman for skilled technical assistance.

\section{REFERENCES}

Dym, M. \& FAwCETT, D. W. (1970) The blood-testis barrier in the rat and the physiological compartment of the seminiferous epithelium. Biol. Reprod. 3, 308-326.

EISENBERG, F., JR (1967) D-Myo-inositol-1-phosphate as product of cyclization of glucose-6-phosphate and substrate for a specific phosphatase in rat testis. F. biol. Chem. 242, 1375-1382.

Eisenberg, F., JR \& Bolden, A. H. (1964) The reproductive tract as site of synthesis and secretion of inositol in the male rat. Nature, Lond. 202, 599-600.

Howard, C. F., JR \& ANDerson, L. (1967) Metabolism of myo-inositol in animals. II. Complete catabolism of myo-inositol- ${ }^{-1} \mathrm{C}$ by rat kidney slices. Archs Biochem. Biophys. 118, 332-339.

Koskimaes, A. I., Kormano, M. \& Alfthen, O. (1973) Proteins of the seminiferous tubule in manevidence for a blood-testis barrier. 7. Reprod. Fert. 32, 79-89.

Lewin, L. M. (1967) The role of myo-inositol in cellular metabolism. Georgetown Univ. med. Cent. Bull. 20, 131-136. 
Lewin, L. M., Szeinberg, A. \& LepkifKer, E. (1973) Gas chromatographic measurement of myoinositol in human blood, cerebrospinal fluid, and seminal fluid. Clin. chim. Acta, 45, 361-368.

Mann, T. (1964) The Biochemistry of Semen and of the Male Reproductive Tract. Methuen, London.

Melampy, R. M. \& Mason, R. B. (1957) Androgen and the myo-inositol content of the male accessory organs of the rat. Proc. Soc. exp. Biol. Med. 96, 405-408.

Middleton, A. \& Setchell, B. P. (1972) The origin of inositol in the rete testis fluid of the ram. 7. Reprod. Fert. 30, 473-475. 